\title{
Somatic cell counts and bacteriological status in quarter foremilk samples of cows in Hesse, Germany-A longitudinal study
}

\author{
D. Schwarz, ${ }^{\star}$ U. S. Diesterbeck, ${ }^{\star}$ K. Failing,† S. König,‡ K. Brügemann,‡ M. Zschöck,§ W. Wolter,\# \\ and C.-P. Czerny ${ }^{* 1}$ \\ *Department of Animal Sciences, Division of Microbiology and Animal Hygiene, Georg-August-University Göttingen, Burckhardtweg 2 , \\ D-37077 Göttingen, Germany \\ †Unit for Biomathematics and Data Processing, Faculty of Veterinary Medicine, Justus-Liebig-University Giessen, Frankfurter Straße 95, \\ D-35392 Giessen, Germany \\ ‡Department of Animal Sciences, Division of Animal Genetics, Georg-August-University Göttingen, Albrecht-Thaer-Weg 3, D-37075 Göttingen, \\ Germany \\ SLandesbetrieb Hessisches Landeslabor, Schubertstraße 60, D-35392 Giessen, Germany \\ \#Regierungspräsidium Giessen, Milk Control, Schanzenfeldstraße 8, D-35578 Wetzlar, Germany
}

\begin{abstract}
Somatic cell counts (SCC) are generally used as an indicator of udder health. Currently in Germany, 100,000 cells $/ \mathrm{mL}$ is the threshold differentiating infected and noninfected mammary glands. The aim of our study was the detailed analysis of udder health in a representative part of the dairy cow population in Hesse, Germany. Between 2000 and 2008, 615,187 quarter foremilk samples were analyzed. In addition to evaluation of distribution of SCC and prevalence of mastitis pathogens, pathogen prevalence was also calculated depending on SCC. The data indicated that $38 \%$ of all samples had SCC $>100,000$ cells $/ \mathrm{mL}$ and $62 \%$ showed SCC $\leq 100,000$ cells $/ \mathrm{mL} ; 31 \%$ of all samples revealed $\mathrm{SCC} \leq 25,000$ cells $/ \mathrm{mL}$. Coagulasenegative staphylococci were the dominant pathogens in the Hessian quarter foremilk samples $(17.17 \%$ of all samples) followed by Corynebacterium spp. (13.56\%), Streptococcus uberis (8.7\%), and Staphylococcus aureus (5.01\%). Mastitis pathogens were detected in $83 \%$ of all samples with SCC >100,000 cells/mL. However, the prevalence of mastitis pathogens in the SCC range from 1,000 to $\leq 100,000$ cells $/ \mathrm{mL}$ was $8.5 \%$ ( $5.51 \%$ minor pathogens, $2.01 \%$ major pathogens, and $0.98 \%$ other pathogens). For farms producing high quality milk, exceptional hygiene management is compulsory. One of the farms randomly selected showed clearly different results from the Hessian survey. Fifteen percent more samples lay in the SCC range $\leq 100,000$ cells $/ \mathrm{mL}$ with a lower prevalence of mastitis pathogens of $1.91 \%(1.03 \%$ minor pathogens, $0.83 \%$ major pathogens, and $0.05 \%$ other pathogens). Based on these results, inflammatory processes can obviously be detected in mammary glands
\end{abstract}

Received March 3, 2010.

Accepted September 1, 2010

${ }^{1}$ Corresponding author: cczerny@gwdg.de of udder quarters healthy according to the current definitions. However, we argue that such inflammation can be detected by examination of the relationship of immune cells in milk.

Key words: low somatic cell count, prevalence of mastitis pathogens, udder health status

\section{INTRODUCTION}

Mastitis is the most costly disease in milk production worldwide, and approximately 70 to $80 \%$ of the financial losses are caused by subclinical mastitis (Reneau and Packard, 1991; Seegers et al., 2003). Subclinical mastitis is characterized by decreased milk production, altered composition of the secretion, and presence of bacteria, but without any visible changes in milk and udder (Harmon, 1994).

For mastitis diagnosis, traditional and well-established tests including SCC and microbial culture-based methods are standard (Viguier et al., 2009). Several SCC cut-offs distinguishing infected and noninfected mammary glands and indicating IMI have been evaluated and discussed in the literature (Schepers et al., 1997; Schukken et al., 2003). According to current definitions of udder health in Germany, quarter foremilk samples with SCC $\leq 100,000$ cells $/ \mathrm{mL}$ are in the physiological range (DVG, 2002). It is well known that the crossover of normal cellular defense in the mammary gland into an inflammatory reaction starts at a level of $>100,000$ cells/mL (Harmon, 1994; DVG, 2002). However, SCC vary with status of lactation, age, stress of the animals, time and frequency of milking, season, and, mainly, udder infection status (Dohoo and Meek, 1982; Harmon, 1994).

The implementation of classical mastitis prevention programs (Neave et al., 1969) in combination with the introduction of penalty limits for bulk milk SCC have led to substantial progress in controlling subclinical 
mastitis worldwide. The geometric bulk milk SCC in Hesse, Germany, was 255,000 cells/mL in 1993 and decreased to 200,000 cells/mL in 2008 (HVL, 1994, 2009). A decrease in the geometric bulk milk SCC from 600,000 cells/mL in 1971 to 200,000 cells/mL in 2002 was observed in the Netherlands (Sampimon et al., 2005). In Finland, the geometric bulk milk SCC decreased from 325,000 cells $/ \mathrm{mL}$ to 132,000 cells $/ \mathrm{mL}$ between 1988 and 2002 (Myllys et al., 1998; Pitkälä et al., 2004). A moderate decrease of the geometric bulk milk SCC from 356,000 cells $/ \mathrm{mL}$ in 1998 to 316,000 cells $/ \mathrm{mL}$ in 2005 was described evaluating the data of one large US milk cooperative in New York State (Nightingale et al., 2008). In addition to mastitis control programs, the selection of animals showing low SCC in animal breeding programs might have had a strong influence on the development of mastitis pathogens. In particular, the prevalence of Staphylococcus aureus decreased. Data for Staph. aureus are also available for the German federal state of Hesse, Finland, the Netherlands, and the state of Wisconsin (United States). In Hesse, Staph. aureus showed a prevalence of $13.0 \%$ in 1995 and $2.9 \%$ in 2008 (LHL, 2009). In Finland, the prevalence of the bacteria was reduced from $5.1 \%$ in 1988 (Myllys et al., 1998) to $3.4 \%$ in 2001 (Pitkälä et al., 2004). The prevalence of Staph. aureus in the Netherlands decreased from $6.2 \%$ in 1973 to $1.8 \%$ in 2003 (Sampimon et al., 2009). In Wisconsin, the proportion of Staph. aureus in all culture-positive samples decreased from $17.7 \%$ in 1994 to a value of 9.7\% in 2001 (Makovec and Ruegg, 2003). In contrast, CNS are currently the most isolated pathogens from milk samples in many countries (Pitkälä et al., 2004; Piepers et al., 2007; Sampimon et al., 2009).

The objective of our research was a detailed evaluation of the udder health situation in a representative part of the dairy cow population in Hesse, Germany, analyzing the distribution of SCC, prevalence of mastitis pathogens, and prevalence of mastitis pathogens in dependence of SCC. Additionally, for a more detailed evaluation of udder health in cows with low SCC and for comparison with the total Hessian average, a single farm practicing exceptional hygiene management was analyzed. However, because mastitis prevention programs have been implemented in Hesse, Germany, for many years, a high level of udder health could be expected.

\section{MATERIALS AND METHODS}

\section{Animals and Farms}

From 2000 to 2008, 615,187 quarter foremilk samples were taken from dairy cows in the German federal state of Hesse and analyzed by the Animal Health Services
(Hesse, Germany). This random test represented approximately $12.5 \%$ of all Hessian dairy cows. Samples were collected from farms producing high quality milk ( $\mathrm{n}=98,430 ; 16 \%$ of all samples), from conventional producing farms ( $\mathrm{n}=412,175 ; 67 \%$ of all samples $)$, and from farms with severe udder health problems $(\mathrm{n}=$ 104,$852 ; 17 \%$ of all samples). Almost all lactating cows of the farms were tested.

In addition, one farm (A) with exceptional hygiene management for the production of high quality milk was randomly selected to evaluate its cytobacteriological status; 12,660 quarter foremilk samples were taken on that farm from 1995 to 2003 . According to the legislative requirements in Germany, farms producing high quality milk have to perform monthly SCC and bacteriological examinations of quarter foremilk samples from all lactating cows.

On farm A, 60 Holstein-Friesian cows were housed in a pen barn and milked twice a day in a milking parlor. The average herd milk yield averaged $9,000 \mathrm{~kg} / \mathrm{yr}$.

\section{Milk Sampling}

Quarter foremilk samples were obtained according to DVG (2000) standards. Before milking, teat ends were scrubbed with $70 \%$ ethanol and the first 2 squirts of milk were discarded. A volume of $10 \mathrm{~mL}$ of milk per udder quarter was collected in a sterile 14-mL plastic sample tube (Greiner Bio-one, Frickenhausen, Germany).

\section{Laboratory Analysis}

Somatic cells were determined using a Fossomatic 5000 (Foss Electric, Hillerød, Denmark) and used as guideline for the selection of udder quarters for bacteriological analysis. Quarter foremilk samples showing SCC $>100,000$ cells $/ \mathrm{mL}$ were cultured categorically. All samples of a herd with $\mathrm{SCC} \leq 100,000$ cells $/ \mathrm{mL}$ were only examined bacteriologically when highly contagious mastitis pathogens such as Staph. aureus, Streptococcus agalactiae, or group $\mathrm{G}$ streptococci were present. Furthermore, all samples from farms producing high quality milk were analyzed bacteriologically independent from SCC.

Culture and isolate identification were performed according to IDF (1981) standards. Promptly after collecting the quarter foremilk samples and cooled transportation to the laboratory, about $10 \mu \mathrm{L}$ of milk was streaked onto a quadrant of a $7 \%$ bovine blood agar plate containing $0.05 \%$ esculin (Merck, Darmstadt, Germany) and incubated for $48 \mathrm{~h}$ at $37^{\circ} \mathrm{C}$; the plates were examined after 24 and $48 \mathrm{~h}$ of incubation. Isolates were classified into (1) major pathogens: Staph. aureus, Strep. agalactiae, Streptococcus dysgalactiae, Streptococ- 
cus uberis, Escherichia coli, coliforms (e.g., Klebsiella spp., Serratia spp., Enterobacter spp., other Enterobacteriaceae); (2) minor pathogens: CNS, Corynebacterium spp.; and (3) other pathogens: Arcanobacterium pyogenes, Proteus, Prototheca zopfii, Pseudomonas spp., group G streptococci (predominantly Streptococcus canis), yeasts, and fungi. Contaminated samples were defined as a mixture of at least 2 environmental type organisms without isolation of a major mastitis pathogen.

\section{Statistical Analysis}

The data sets of the results of the SCC examinations in Hesse and on farm A were divided into 15 different SCC ranges from $\leq 1,560$ to $>12,800,000$ cells $/ \mathrm{mL}$. Their limits were calculated using a logarithmic partition to the base 2 of the SCC scale according to the SCS standard $\left[\mathrm{SCS}=\log _{2}(\mathrm{SCC} / 100,000)+3\right.$; Ali and Shook, 1980]. All records with a missing SCC value or a value $<1,000$ cells $/ \mathrm{mL}$ were excluded from the data sets (Hessian survey: $\mathrm{n}=27,281$; farm $\mathrm{A}: \mathrm{n}=122$ ). These records were not included in the total numbers (Hessian survey: $\mathrm{n}=615,187$; farm $\mathrm{A}: \mathrm{n}=12,660$ ). For a more practical interpretation, a wider scale range was determined according to the SCS standard defining 4 SCC groups: group I: $\leq 6,250$ cells $/ \mathrm{mL}$; group II: $>6,250$ to $\leq 25,000$ cells $/ \mathrm{mL}$; group III: $>25,000$ to $\leq 100,000$ cells/mL; and group IV: $>100,000$ cells $/ \mathrm{mL}$.

Distributions of SCC in Hesse and on farm A were tested for Gaussian distribution using the Shapiro and Wilk test as well as the Chi-squared test (BMDP Statistical Solutions Ltd., Cork, Ireland). Becaue of technical reasons, random tests of 2,000 records of each data set were used for the calculation of the Shapiro and Wilk test, whereas the whole data sets of both Hesse and dairy farm A were used for the Chi-squared test.

Additionally, a subset comprising data of Hesse from $2003(\mathrm{n}=79,204)$ was analyzed to identify the effect of fixed and random effects on SCC by applying a linear mixed model. Selection of data for verification of results, as presented in Figure 1, was done because of computational limitations. The SCC were log-transformed according to Ali and Shook (1980) to obtain better statistical properties. The data subset was analyzed using the MIXED procedure of SAS 9.1 (SAS Institute Inc., Cary, NC) and the following statistical model

$$
\mathrm{Y}_{\mathrm{ijk}}=\mu+\mathrm{H}_{\mathrm{i}}+\mathrm{Q}_{\mathrm{j}}+\mathrm{e}_{\mathrm{ijk}},
$$

where $\mathrm{Y}_{\mathrm{ijk}}=$ observed value for SCS in herd $\mathrm{i}$ and udder quarter $\mathrm{j}$ of cow $\mathrm{k} ; \mu=$ overall mean; $\mathrm{H}_{\mathrm{i}}=$ random effect of herd $\mathrm{i}$ ( $\mathrm{i}=1$ to 1,338$) ; \mathrm{Q}_{\mathrm{j}}=$ fixed effect of quarter $\mathrm{j}(\mathrm{j}=1$ to 4$)$; and $\mathrm{e}_{\mathrm{ijk}}=$ random error term.

In addition to the SCC data $(\mathrm{n}=235,556)$, the results of the bacteriological examinations of 145,965 quarter foremilk samples analyzed in Hesse were available for the period 2000 to 2003. On farm A, the bacteriological data could be evaluated for the period 1995 to 2003 (n $=12,660)$. For statistical calculation, the classification of the bacteriological results into major, minor, and other pathogens was carried out according to Reneau (1986). The classification and calculation of the frequency of each pathogen was performed independently from SCC and depending on 15 SCC ranges defined above using SAS 9.1 (SAS Institute Inc.).

The data subset comprising results from 2003 ( $\mathrm{n}=$ $79,204)$ was also analyzed to identify the impact of fixed and random effects on specific pathogens by applying a generalized linear mixed model. Because pathogens are classified as binary traits, the residuals cannot be normally distributed. The best function to describe the relationship between the dependent and independent variables is not linear but S-shaped. This is the primary reason why a linear logistic model with mixed effects was used. As described by König et al. (2005), the probability of observing the event of interest (e.g., prevalence of the pathogen) was

$$
\pi_{\mathrm{i}}=\operatorname{Prob}\left(\mathrm{Y}_{\mathrm{i}}=1 \mid \theta\right),
$$

where $\theta$ is a parameter vector including fixed and random effects. The logit of the observation $Y_{i}$ was

$$
\log \left[\frac{\pi_{i}}{1-\pi_{i}}\right]=\eta_{i} .
$$

Because $\pi$ is the probability of $\mathrm{Y}=1$, it follows that 1 $-\pi$ is the probability of $\mathrm{Y}=0$ and so $\frac{\pi}{1-\pi}$ is the ratio of the 2 probabilities, which, when stated in the form of odds, gives the odds of having $\mathrm{Y}=1$. Analysis of variance of the measurements was carried out using logistic models implemented in the SAS glimmix macro (Wolfinger and O'Connell, 1993) that included the fixed effects of the udder quarter and the defined SCC group and the random effect of the herd. The $F$-ratios used in the ANOVA are identical to the Wald/rank(K) $F$-statistics as defined by Littell et al. (1999). Wald-type tests were also used to identify significant fixed effects on different pathogens (type III tests of fixed effects).

The final generalized linear model used to determine the impact of fixed and random effects on prevalence of pathogens was 


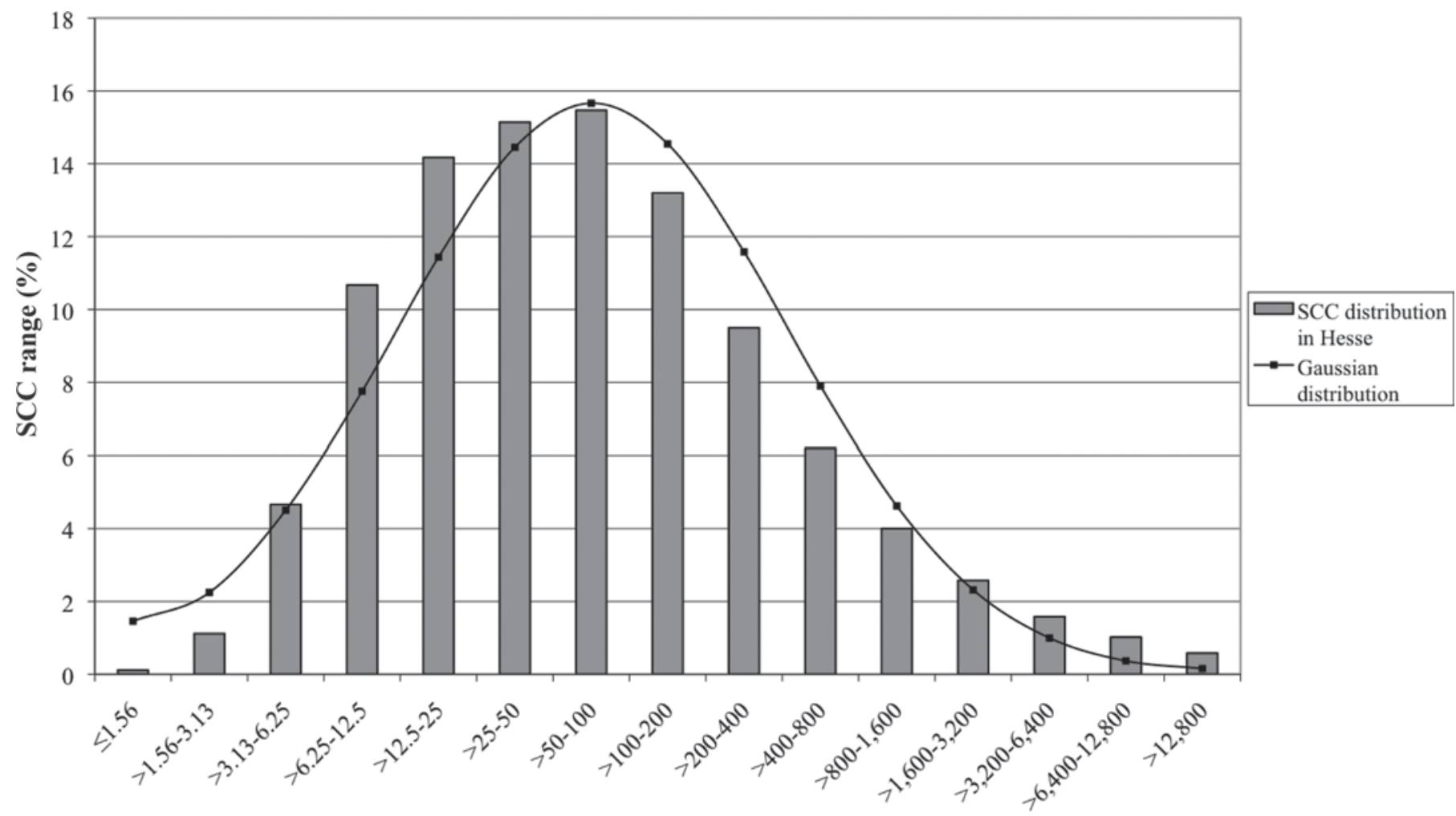

SCC range $(\times 1,000$ cells $/ \mathrm{mL})$

Figure 1. Statistical distribution of SCC of all quarter foremilk samples analyzed in the German federal state of Hesse taken from 2000 to $2008(\mathrm{n}=615,187)$ by classification into 15 SCC ranges using a logarithmic partition to the base 2 of the SCC scale according to the SCS standard. The bar charts show the distribution of SCC observed in Hesse, and the line shows the distribution of SCC expected by the exact Gaussian distribution.

$$
\operatorname{logit}\left(\pi_{r s t u}\right)=\log \left[\frac{\pi_{r s t}}{1-\pi_{r s t}}\right]=\eta_{r s t}=\varphi+\gamma_{r}+\lambda_{s}+\varepsilon_{t},
$$

where $\pi_{r s t u}=$ probability of occurrence of a pathogen in udder quarter $s$ and SCC group $r$ for cow $u$ in herd $t ; \varphi$ $=$ overall mean effect; $\gamma_{r}=$ fixed effect of SCC-group; $\lambda_{s}=$ fixed effect of udder quarter; and $\varepsilon_{t}=$ random effect of the herd

\section{RESULTS}

\section{Evaluation of Udder Health in Hessian Dairy Farms}

For the evaluation of udder health in Hesse, Germany, a data set with the results of 615,187 quarter foremilk samples was used. The samples were derived from farms with different levels of udder health. In general, farms producing high quality milk showed a bulk tank SCC of 180,000 cells $/ \mathrm{mL}$. The bulk tank SCC of conventional milk producers averaged 200,000 cells/mL, whereas the bulk tank SCC in farms with massive udder health problems was higher $(400,000$ cells/mL).
Distribution of SCC. Somatic cell counts of the quarter foremilk samples analyzed ranged from 1,000 to $30,000,000$ cells $/ \mathrm{mL}$. The distribution of all quarter foremilk samples in the 15 SCC ranges is illustrated in Figure 1. In total, $38 \%$ of all quarter foremilk samples indicated an inflammatory reaction (SCC >100,000 cells $/ \mathrm{mL}$ ) according to the current DVG definitions (DVG, 2002). A high frequency $(62 \%)$ of the samples had SCC in a physiological range $(\leq 100,000$ cells $/$ $\mathrm{mL}$ ). Thirty-one percent of all samples had SCC between 25,000 and 100,000 cells/mL, and $31 \%$ had SCC $\leq 25,000$ cells $/ \mathrm{mL}$.

For a more practical interpretation, 4 SCC groups (I to IV) were defined. Six percent of the quarter foremilk samples analyzed in Hesse belonged to group I $(\leq 6,250$ cells $/ \mathrm{mL}), 25 \%$ belonged to group II $(>6,250$ to $\leq 25,000$ cells $/ \mathrm{mL}$ ), $31 \%$ belonged to group III $(>25,000$ to $\leq 100,000$ cells $/ \mathrm{mL})$, and $38 \%$ belonged to group IV $(>100,000$ cells $/ \mathrm{mL})$.

The distribution of the logarithm of SCC in Hesse was similar to a Gaussian distribution (Figure 1). However, the goodness of fit test for normality according to the Shapiro and Wilk test as well as the chi-squared 
Table 1. Least squares means and standard error of mean for SCS in different udder quarter positions from 79,204 quarter foremilk samples analyzed in Hesse, Germany, in 2003

\begin{tabular}{lcc}
\hline & \multicolumn{2}{c}{ SCS } \\
\cline { 2 - 3 } Udder quarter & LSM & SEM \\
\hline Front right & $2.45^{\mathrm{a}}$ & 0.02 \\
Rear right & $2.52^{\mathrm{b}}$ & 0.02 \\
Front left & $2.31^{\mathrm{c}}$ & 0.02 \\
Rear left & $2.45^{\mathrm{a}}$ & 0.02 \\
\hline
\end{tabular}

${ }^{\mathrm{a}-\mathrm{C}}$ Least squares means with different letters differ significantly at $P$ $<0.05$.

test showed a significant deviation $(P<0.001)$ from the exact Gaussian distribution. In particular, in both tails of the distribution deviations from normality could be observed (Figure 1). More samples than expected were observed on the left side of the middle area of the Gaussian distribution. In contrast, fewer samples than expected were observed on the right side of the distribution.

To evaluate the effect of quarter position on SCC, a data set including 79,204 quarter foremilk samples tested in 2003 was analyzed as an exemplar using a statistical model. The data from 2003 were representative of the whole data set from 2000 to 2008. For statistical reasons, SCC were transformed to SCS. The analysis indicated a highly significant $(P<0.001)$ effect of quarter position on SCS. The mean SCS value of the front left quarter was significantly $(P<0.05)$ lower than that of the other 3 quarters (Table 1). In contrast, the highest mean SCS value could be calculated for the rear right quarter. In total, the mean SCS of both front quarters of 2.38 (SEM 0.01) was significantly ( $P$
$<0.001)$ lower than in both rear quarters (2.49; SEM $0.01)$.

Distribution of Bacteriological Results. A high frequency of the quarter foremilk samples (62\%) taken between 2000 and 2008 lay in a physiological range with SCC $\leq 100,000$ cells/mL and offered a proper standard of udder health. Bacteriological results were available for 145,065 of the 235,556 quarter foremilk samples taken from 2000 to 2003. The prevalence of mastitis pathogens in the samples examined was $51.96 \%$ (Table 2 ). The most frequently isolated pathogens were CNS (33.05\%), followed by Corynebacterium spp. (26.1\%), Strep. uberis (16.75\%), Staph. aureus (9.63\%), coliforms (2.21\%), Strep. dysgalactiae (1.61\%), E. coli $(1.17 \%)$, and Strep. agalactiae (0.55\%). Other pathogens were detected in $4.31 \%$ of all culture-positive samples. A proportion of $4.62 \%$ of all culture-positive samples was contaminated.

Approximately $40 \%(\mathrm{n}=60,327)$ of all quarter foremilk samples with $\mathrm{SCC} \leq 100,000$ cells $/ \mathrm{mL}$ were analyzed bacteriologically (Table 3 ). One fraction (n $=30,759$ ) of these samples was cultured because of the presence of highly contagious mastitis pathogens such as Staph. aureus, Strep. agalactiae, or group G streptococci in a herd. The remaining fraction ( $\mathrm{n}=$ 29,568 ) originated from high quality milk producers whose samples were generally analyzed bacteriologically. Pathogens were found in $8.5 \%$ of these quarter foremilk samples. Minor pathogens (Corynebacterium spp., CNS) as well as major pathogens (Staph. aureus, Strep. uberis) were detected beginning at an SCC level of $\leq 1,560$ cells $/ \mathrm{mL}$ (Table 3 ). Within the SCC groups I to III, the frequencies of minor pathogens $(5.51 \%)$, major pathogens $(2.01 \%)$, and other pathogens $(0.98 \%)$

Table 2. Prevalence and distribution of mastitis pathogens in quarter foremilk samples analyzed bacteriologically in the German federal state of Hesse between 2000 and $2003(\mathrm{n}=145,065)$

\begin{tabular}{|c|c|c|c|}
\hline Item & $\mathrm{n}$ & $\begin{array}{l}\text { All quarters } \\
(\%)^{1}\end{array}$ & $\begin{array}{c}\text { Culture- } \\
\text { positive }(\%)^{2}\end{array}$ \\
\hline Quarters analyzed bacteriologically & 145,065 & & \\
\hline Culture-negative quarters & 69,691 & 48.04 & \\
\hline Culture-positive quarters & 75,374 & 51.96 & \\
\hline Staphylococcus aureus & 7,262 & 5.01 & 9.63 \\
\hline Streptococcus agalactiae & 414 & 0.29 & 0.55 \\
\hline Streptococcus dysgalactiae & 1,211 & 0.83 & 1.61 \\
\hline Streptococcus uberis & 12,623 & 8.70 & 16.75 \\
\hline Escherichia coli & 882 & 0.61 & 1.17 \\
\hline Coliforms $^{3}$ & 1,664 & 1.15 & 2.21 \\
\hline CNS & 24,913 & 17.17 & 33.05 \\
\hline Corynebacterium spp. & 19,673 & 13.56 & 26.10 \\
\hline Other pathogens ${ }^{4}$ & 3,246 & 2.24 & 4.31 \\
\hline Contamination & 3,486 & 2.40 & 4.62 \\
\hline
\end{tabular}


were higher than expected. Concerning the total number of quarter foremilk samples with SCC values $\leq 100,000$ cells/mL analyzed from 2000 to $2003(\mathrm{n}=150,818)$, no mastitis pathogens were detected in 94 to $98 \%$ of the cases within the individual SCC ranges (Table 3).

Mastitis pathogens were detected in $82.91 \%$ of the 84,738 quarter foremilk samples with SCC values $>100,000$ cells $/ \mathrm{mL}$ (group IV) analyzed from 2000 to 2003 (Table 3); CNS were the most frequently isolated pathogens. Their prevalence decreased from a maximum of $30.77 \%$ (SCC 100,000 to 200,000 cells $/ \mathrm{mL}$ ) to $12.03 \%$ ( $\mathrm{SCC}$ of $>12,800,000$ cells $/ \mathrm{mL}$ ). Staphylococcus aureus were predominantly identified in samples with SCC $>400,000$ cells $/ \mathrm{mL}$ (10.49 to $14.29 \%)$. Corynebacterium spp. were isolated with higher frequencies in samples with SCC between 100,000 and 800,000 cells/ $\mathrm{mL}$. Streptococcus uberis showed the highest prevalences ( 20.34 to $24.54 \%$ ) in samples with SCC $>1,600,000$ cells/ $\mathrm{mL}$. The prevalence of Strep. agalactiae was generally very low $(<1 \%)$. However, Strep. agalactiae was more frequently detected ( 0.53 to $0.80 \%$ ) in the SCC range from 400,000 to $12,800,000$ cells $/ \mathrm{mL}$. The major pathogen Strep. dysgalactiae was predominantly identified (3.01 to $6.55 \%$ ) in samples with SCC $>800,000$ cells/ $\mathrm{mL}$. The prevalence of $E$. coli increased from $0.47 \%$ at SCC of $>100,000$ to 200,000 cells $/ \mathrm{mL}$ to a maximum of $8.29 \%$ at $\mathrm{SCC}$ of $>12,800,000$ cells $/ \mathrm{mL}$. Coliforms were predominantly isolated in samples showing SCC from 800,000 to $>12,800,000$ cells $/ \mathrm{mL}$. The prevalence of other pathogens in group IV ranged between 2 and $8 \%$. The proportion of contaminated samples decreased at increasing SCC.

As an examplar, a data set including all quarter foremilk samples $(\mathrm{n}=79,204)$ tested cytobacteriologically in 2003 was evaluated applying a generalized linear mixed model for the identification of fixed and random effects on the prevalence of the individual pathogens. The analysis indicated that the position of the udder quarter influenced the prevalence of most pathogens significantly (Table 4). The major pathogen Staph. aureus was significantly $(P<0.001)$ more frequently isolated from the front right quarter than from the other 3 quarters (Table 5). The highest prevalences for Strep. agalactiae and Corynebacterium spp. were found in front quarters, whereas Strep. dysgalactiae and CNS were predominantly isolated from rear quarters. Streptococcus uberis and other pathogens showed the highest prevalences in the front right and rear left quarters. Coliforms and E. coli were predominantly found in right quarters. Most contaminated samples originated from rear quarters. The proportion of samples without any isolation of pathogens was significantly $(P<0.001)$ higher in the front left quarter and lower in the rear left quarter than in right quarters.
A significant $(P<0.001)$ influence on the prevalence of all pathogens with the exception of Strep. agalactiae and Strep. dysgalactiae could be calculated for the 4 SCC groups defined (Table 4). The prevalence of most pathogens in groups I and II was significantly lower than in those of groups III and IV (Table 6). The proportion of samples without any isolation of pathogens decreased significantly $(P<0.001)$ with increasing SCC groups. The distribution of Strep. agalactiae, Strep. dysgalactiae, and E. coli depending on the 4 SCC groups could not be evaluated because of their extremely low prevalences in groups I to III.

\section{Evaluation of Udder Health on Farm A}

Farm A was chosen randomly to show the distribution of SCC and bacteriological results in a single farm practicing exceptional hygiene. The evaluation of udder health in this farm was based on the results of 12,660 quarter foremilk samples analyzed.

Distribution of $S C \boldsymbol{C}$. Somatic cell counts of all quarter foremilk samples taken on farm A lay in a range between 1,000 and 24,000,000 cells/mL; the distribution of SCC on farm A is presented in Figure 1. A total of $23 \%$ of all quarter foremilk samples on farm A indicated an inflammatory reaction (SCC >100,000 cells $/ \mathrm{mL}$ ) according to the current DVG definitions (DVG, 2002) of udder health, representing 15\% fewer samples than in the Hessian survey. The high frequency (77\%) of samples with SCC $\leq 100,000$ cells $/ \mathrm{mL}$ became evident on this farm, too, and was $15 \%$ above the Hessian average. Forty percent of all samples revealed SCC between 25,000 and 100,000 cells $/ \mathrm{mL}$ and $37 \%$ revealed SCC $\leq 25,000$ cells $/ \mathrm{mL}$, ranging 9 and $6 \%$, respectively, above the Hessian average.

Dividing SCC frequencies of farm A into the same SCC groups (I to IV) used for the Hessian surveillance, $9 \%$ of the quarter foremilk samples belonged to group I, $28 \%$ to group II, $40 \%$ to group III, and $23 \%$ to group IV.

Again, the goodness-of-fit test for normality according to the Shapiro and Wilk test as well as the Chisquared test applied to the distribution of SCC on farm A (Figure 2) showed a significant deviation $(P<0.001)$ from the exact Gaussian distribution, as already seen for the Hessian samples and for the same reasons. However, the distribution observed was close to the normal distribution (Figure 2).

Distribution of Bacteriological Results. Bacteriological results were available for all 12,660 quarter foremilk samples taken from 1995 to 2003. The prevalence of mastitis pathogens was $21.65 \%$ (Table 7). Pathogens isolated most frequently were CNS $(35.32 \%)$, followed by Corynebacterium spp. (29.92\%), Strep. ub- 
Table 3. Prevalence and distribution of mastitis pathogens (\%) isolated from quarter foremilk samples obtained in the German federal state of Hesse within 2000 to 2003 ( $\mathrm{n}=$ $235,556)$ in 15 different SCC ranges

\begin{tabular}{|c|c|c|c|c|c|c|c|c|c|c|c|c|}
\hline \multirow[b]{2}{*}{$\begin{array}{l}\text { Group/SCC range } \\
(\times 1,000 \text { cells } / \mathrm{mL})\end{array}$} & \multirow[b]{2}{*}{$\mathrm{n}$} & \multicolumn{6}{|c|}{ Major pathogens ${ }^{1}$} & \multicolumn{2}{|c|}{ Minor pathogens } & \multirow[b]{2}{*}{ Others $^{2}$} & \multirow[b]{2}{*}{$\begin{array}{c}\text { No } \\
\text { pathogens }\end{array}$} & \multirow[b]{2}{*}{ Contam. ${ }^{3}$} \\
\hline & & $\begin{array}{l}\text { Staph. } \\
\text { aureus }\end{array}$ & $\begin{array}{l}\text { Strep. } \\
\text { agalactiae }\end{array}$ & $\begin{array}{c}\text { Strep. } \\
\text { dysgalactiae }\end{array}$ & $\begin{array}{l}\text { Strep. } \\
\text { uberis }\end{array}$ & E. coli & Coliforms & CNS & $\begin{array}{c}\text { Coryne- } \\
\text { bacterium spp. }\end{array}$ & & & \\
\hline \multicolumn{13}{|l|}{ Group I } \\
\hline$\leq 1.56$ & 415 & 0.48 & 0 & 0 & 0.24 & 0 & 0 & 0.48 & 0.24 & 0 & 98.56 & 0 \\
\hline$>1.56-3.13$ & 3,470 & 0.35 & 0 & 0 & 0.09 & 0 & 0.03 & 0.58 & 0.35 & 0.06 & 98.40 & 0.14 \\
\hline$>3.13-6.25$ & 12,681 & 0.54 & 0 & 0 & 0.13 & 0 & 0.04 & 0.66 & 0.28 & 0.13 & 98.09 & 0.13 \\
\hline \multicolumn{13}{|l|}{ Group II } \\
\hline$>6.25-12.5$ & 26,815 & 0.42 & 0.01 & 0.01 & 0.14 & 0 & 0.04 & 0.83 & 0.48 & 0.14 & 97.79 & 0.14 \\
\hline$>12.5-25$ & 33,837 & 0.43 & 0.02 & 0.01 & 0.15 & 0 & 0.06 & 0.78 & 0.94 & 0.20 & 97.19 & 0.22 \\
\hline \multicolumn{13}{|l|}{ Group III } \\
\hline$>25-50$ & 36,246 & 0.47 & 0.03 & 0.02 & 0.18 & 0.01 & 0.06 & 0.92 & 1.39 & 0.13 & 96.59 & 0.20 \\
\hline$>50-100$ & 37,354 & 0.56 & 0.06 & 0.02 & 0.41 & 0.01 & 0.09 & 1.79 & 1.95 & 0.15 & 94.65 & 0.31 \\
\hline \multicolumn{13}{|l|}{ Group IV } \\
\hline$>100-200$ & 30,406 & 3.73 & 0.21 & 0.36 & 10.77 & 0.47 & 1.32 & 30.77 & 27.21 & 2.54 & 18.26 & 4.36 \\
\hline$>200-400$ & 21,421 & 6.46 & 0.37 & 0.92 & 14.29 & 0.65 & 1.51 & 30.10 & 22.53 & 2.64 & 16.48 & 4.05 \\
\hline$>400-800$ & 13,426 & 10.49 & 0.64 & 1.69 & 16.13 & 0.89 & 1.43 & 26.95 & 18.95 & 3.40 & 16.19 & 3.24 \\
\hline$>800-1,600$ & 8,513 & 13.83 & 0.80 & 3.01 & 16.43 & 1.52 & 2.69 & 22.62 & 15.11 & 4.26 & 16.43 & 3.30 \\
\hline$>1,600-3,200$ & 5,270 & 13.78 & 0.70 & 3.29 & 20.34 & 2.03 & 4.22 & 20.53 & 11.37 & 6.09 & 14.86 & 2.79 \\
\hline$>3,200-6,400$ & 3,011 & 11.94 & 0.53 & 3.19 & 24.54 & 2.56 & 3.26 & 17.36 & 9.48 & 7.25 & 17.70 & 2.19 \\
\hline$>6,400-12,800$ & 1,943 & 14.29 & 0.88 & 4.23 & 21.71 & 5.00 & 4.18 & 15.11 & 6.03 & 8.10 & 18.82 & 1.65 \\
\hline$>12,800$ & 748 & 11.36 & 0.53 & 6.55 & 23.26 & 8.29 & 3.48 & 12.03 & 3.74 & 7.49 & 21.68 & 1.59 \\
\hline
\end{tabular}

${ }^{1}$ Major pathogens: Staphylococcus aureus; Streptococcus (Strep.) agalactiae; Strep. dysgalactiae; Strep. uberis; Escherichia coli; Coliforms = Klebsiella spp., Serratia spp., Enterobacter spp., other Enterobacteriaceae.

Other pathogens: Arcanobacterium pyogenes, Proteus, Prototheca zopfii, Pseudomonas spp., group G streptococci, yeasts, and fungi.

${ }^{3}$ Contaminated samples. 
Table 4. Results of ANOVA for the prevalence of the individual pathogens in 79,204 quarter foremilk samples analyzed in Hesse, Germany, in $2003^{1}$

\begin{tabular}{|c|c|c|}
\hline \multirow[b]{2}{*}{ Pathogen } & \multicolumn{2}{|c|}{ Effect } \\
\hline & $\begin{array}{c}\text { Udder } \\
\text { quarter }\end{array}$ & $\begin{array}{l}\text { SCC } \\
\text { group }\end{array}$ \\
\hline Staphylococcus aureus & $* * *$ & $* * *$ \\
\hline Streptococcus agalactiae & * & $\mathrm{NC}$ \\
\hline Streptococcus dysgalactiae & $* *$ & $\mathrm{NC}$ \\
\hline Streptococcus uberis & $* * *$ & $* * *$ \\
\hline Escherichia coli & NS & $* * *$ \\
\hline Coliforms $^{2}$ & $* * *$ & $* * *$ \\
\hline CNS & $* * *$ & $* * *$ \\
\hline Corynebacterium spp. & NS & $* * *$ \\
\hline Contamination & **** & $* * *$ \\
\hline Other pathogens ${ }^{3}$ & NS & $* * *$ \\
\hline No pathogens & $* * *$ & $* * *$ \\
\hline
\end{tabular}

${ }^{1}$ Analyzed factors were quarter positions (front right, rear right, front left, and rear left) and SCC group (I $\leq 6,250$ cells $/ \mathrm{mL}$, II $>6,250$ to $\leq 25,000$ cells $/ \mathrm{mL}$, III $>25,000$ to $\leq 100,000$ cells $/ \mathrm{mL}$, IV $>100,000$ cells $/ \mathrm{mL}) ; \mathrm{NC}=$ not calculated.

${ }^{2}$ Coliforms = Klebsiella spp., Serratia spp., Enterobacter spp., other Enterobacteriaceae.

${ }^{3}$ Other pathogens: Arcanobacterium pyogenes, Proteus, Prototheca zopfii, Pseudomonas spp., group G streptococci, yeasts, and fungi.

*** $P<0.001 ;{ }^{*} P<0.01 ;{ }^{*} P<0.05 ; \mathrm{NS}=P>0.05$

eris $(21.71 \%)$, Staph. aureus (5.29\%), coliforms (1.86\%), Strep. dysgalactiae (0.62\%), and E. coli (0.51\%). Other pathogens were detected in $0.80 \%$ of all culture-positive samples. A proportion of $3.98 \%$ of all culture-positive samples was contaminated. The major pathogen Strep. agalactiae could not be isolated from any sample taken on farm A.

Mastitis pathogens were found in $1.91 \%$ of 9,715 quarter foremilk samples showing SCC $\leq 100,000$ cells/ $\mathrm{mL}$ (Table 8). Minor pathogens (CNS) were detected at a minimum of $\leq 1,560$ cells $/ \mathrm{mL}$, whereas major pathogens (Staph. aureus) could be isolated beginning at a level of $>3,130$ to 6,250 cells $/ \mathrm{mL}$. The frequencies of minor pathogens $(1.03 \%)$, major pathogens $(0.83 \%)$, and other pathogens $(0.05 \%)$ were clearly lower within the SCC groups I to III compared with the Hessian averages. No mastitis pathogens were detected in 96 to $99 \%$ of the cases within the individual SCC ranges (Table 8).

Mastitis pathogens were detected in $87.95 \%$ of the 2,905 quarter foremilk samples with SCC values $>100,000$ cells/mL (group IV) analyzed within this period (Table 8); CNS were the most frequently isolated pathogens. Their prevalence decreased from a maximum of $33.62 \%$ (SCC 100,000 to 200,000 cells $/ \mathrm{mL}$ ) to $17.64 \%$ (SCC of $6,400,000$ to $>12,800,000$ cells $/ \mathrm{mL}$ ) and increased again to a level of $33.33 \%$ at SCC $>12,800,000$ cells/ $\mathrm{mL}$. Staphylococcus aureus was predominantly isolated in samples with SCC from $>200,000$ to 6,400,000 cells/
$\mathrm{mL}(3.85$ to $10.16 \%)$. The prevalence of Corynebacterium spp. decreased constantly from $31.83 \%$ at SCC of $>100,000$ to 200,000 cells $/ \mathrm{mL}$ to $8.35 \%$ at SCC of $>12,800,000$ cells/mL. Streptococcus uberis showed prevalences varying between $14.83 \%$ and $35.29 \%$ in the SCC range $>100,000$ cells $/ \mathrm{mL}$. The prevalence of Strep. dysgalactiae increased from $0.06 \%$ at SCC of $>100,000$ to 200,000 cells $/ \mathrm{mL}$ to $8.33 \%$ at SCC of $>12,800,000$ cells $/ \mathrm{mL}$. Streptococcus agalactiae was not detected. The prevalence of $E$. coli in group IV ranged between 0 and $8.33 \%$. The prevalence of coliforms increased from $1.05 \%$ at SCC of $>100,000$ to 200,000 cells $/ \mathrm{mL}$ to $8.33 \%$ at $\mathrm{SCC}$ of $>12,800,000$ cells $/ \mathrm{mL}$, except that no coliform bacteria were isolated in samples showing SCC between $6,400,000$ and $12,800,000$ cells $/ \mathrm{mL}$. The prevalence of other pathogens in group IV lay between 0 and $12 \%$. The proportion of contaminated samples ranged between 0 and $5 \%$.

\section{DISCUSSION}

Udder health status in the German federal state of Hesse was evaluated on the basis of quarter foremilk samples taken from 2000 to 2008. Quarter foremilk samples are accepted for the evaluation of udder health because a high correlation between SCC in foremilk samples and in total representative samples was reported (Dohoo and Meek, 1982). In general, foremilk refers to the first secretions removed from the teat at milking time and represents a portion of cisternal milk (Stockler et al., 2009). It is known that the milk

Table 5. Least squares means for the prevalence of pathogens in different udder quarter positions from 79,204 quarter foremilk samples analyzed in Hesse, Germany, in 2003

\begin{tabular}{lllll}
\hline & \multicolumn{4}{c}{ Udder quarter $^{1}$} \\
\cline { 2 - 5 } Pathogen & FR & RR & FL & RL \\
\hline Staphylococcus aureus & $1.08^{\mathrm{a}}$ & $0.77^{\mathrm{b}}$ & $0.86^{\mathrm{b}}$ & $0.86^{\mathrm{b}}$ \\
Streptococcus agalactiae & $0.30^{\mathrm{ab}}$ & $0.22^{\mathrm{a}}$ & $0.39^{\mathrm{b}}$ & $0.29^{\mathrm{ab}}$ \\
Streptococcus dysgalactiae & $0.51^{\mathrm{a}}$ & $0.64^{\mathrm{ab}}$ & $0.55^{\mathrm{a}}$ & $0.82^{\mathrm{b}}$ \\
Streptococcus uberis & $1.01^{\mathrm{a}}$ & $0.82^{\mathrm{b}}$ & $0.85^{\mathrm{bc}}$ & $0.98^{\mathrm{ac}}$ \\
Escherichia coli & $0.38^{\mathrm{a}}$ & $0.36^{\mathrm{ab}}$ & $0.25^{\mathrm{b}}$ & $0.28^{\mathrm{ab}}$ \\
Coliforms & $0.42^{\mathrm{a}}$ & $0.60^{\mathrm{b}}$ & $0.37^{\mathrm{a}}$ & $0.40^{\mathrm{a}}$ \\
CNS & $4.17^{\mathrm{a}}$ & $4.46^{\mathrm{b}}$ & $4.09^{\mathrm{a}}$ & $4.81^{\mathrm{c}}$ \\
Corynebacterium spp. $_{\text {Contamination }}$ & $3.75^{\mathrm{ab}}$ & $3.73^{\mathrm{ab}}$ & $3.87^{\mathrm{a}}$ & $3.62^{\mathrm{b}}$ \\
Other pathogens & $0.68^{\mathrm{a}}$ & $0.89^{\mathrm{b}}$ & $0.76^{\mathrm{a}}$ & $0.93^{\mathrm{b}}$ \\
No pathogens & $0.07^{\mathrm{a}}$ & $0.06^{\mathrm{a}}$ & $0.06^{\mathrm{a}}$ & $0.08^{\mathrm{a}}$ \\
\hline
\end{tabular}

${ }^{\mathrm{a}-\mathrm{C}}$ Least squares means within the same row with different letters differ significantly at $P<0.05$.

${ }^{1}$ Udder quarter position: $\mathrm{FR}=$ front right, $\mathrm{RR}=$ rear right, $\mathrm{FL}=$ front left, $\mathrm{RL}=$ rear left.

${ }^{2}$ Coliforms $=$ Klebsiella spp., Serratia spp., Enterobacter spp., other Enterobacteriaceae.

${ }^{3}$ Other pathogens: Arcanobacterium pyogenes, Proteus, Prototheca zopfii, Pseudomonas spp., group G streptococci, yeasts, and fungi. 
Table 6. Least squares means for the prevalence of pathogens in the 4 SCC groups defined from 79,204 quarter foremilk samples analyzed in Hesse, Germany, in 2003

\begin{tabular}{lcccc}
\hline & \multicolumn{4}{c}{ SCC group } \\
\cline { 2 - 5 } Pathogen & I & II & III & IV \\
\hline Staphylococcus aureus & $0.37^{\mathrm{ab}}$ & $0.35^{\mathrm{a}}$ & $0.57^{\mathrm{b}}$ & $7^{\mathrm{b}}$ \\
Streptococcus agalactiae & - & - & - & - \\
Streptococcus dysgalactiae & - & - & - & - \\
Streptococcus uberis & $0.03^{\mathrm{a}}$ & $0.03^{\mathrm{a}}$ & $0.07^{\mathrm{a}}$ & $1.04^{\mathrm{b}}$ \\
Escherichia coli & - & - & - & - \\
Coliforms & $0.25^{\mathrm{a}}$ & $0.21^{\mathrm{a}}$ & $0.31^{\mathrm{a}}$ & $2.19^{\mathrm{b}}$ \\
CNS & $1.58^{\mathrm{a}}$ & $1.88^{\mathrm{a}}$ & $3.55^{\mathrm{b}}$ & $27.81^{\mathrm{c}}$ \\
Corynebacterium spp. & $0.83^{\mathrm{a}}$ & $2.30^{\mathrm{b}}$ & $3.78^{\mathrm{c}}$ & $22.78^{\mathrm{d}}$ \\
Contamination & $0.42^{\mathrm{a}}$ & $0.49^{\mathrm{a}}$ & $0.50^{\mathrm{a}}$ & $4.11^{\mathrm{b}}$ \\
Other pathogens & $0.003^{\mathrm{a}}$ & $0.08^{\mathrm{a}}$ & $0.07^{\mathrm{a}}$ & $1.27^{\mathrm{b}}$ \\
No pathogens & $95.78^{\mathrm{a}}$ & $94.00^{\mathrm{b}}$ & $90.05^{\mathrm{c}}$ & $17.52^{\mathrm{d}}$ \\
\hline
\end{tabular}

${ }^{\text {a-d }}$ Least squares means within the same row with different letters differ significantly at $P<0.05$.

${ }^{1} \mathrm{SCC}$ groups: $\mathrm{I}=\leq 6,250$ cells $/ \mathrm{mL}$; II $=>6,250$ to $\leq 25,000$ cells $/ \mathrm{mL} ; \mathrm{III}=>25,000$ to $\leq 100,000$ cells $/ \mathrm{mL}$; $\mathrm{IV}=>100,000$ cells $/ \mathrm{mL}$.

${ }^{2}$ Coliforms = Klebsiella spp., Serratia spp., Enterobacter spp., other Enterobacteriaceae.

${ }^{3}$ Other pathogens: Arcanobacterium pyogenes, Proteus, Prototheca zopfii, Pseudomonas spp., group G streptococci, yeasts, and fungi.

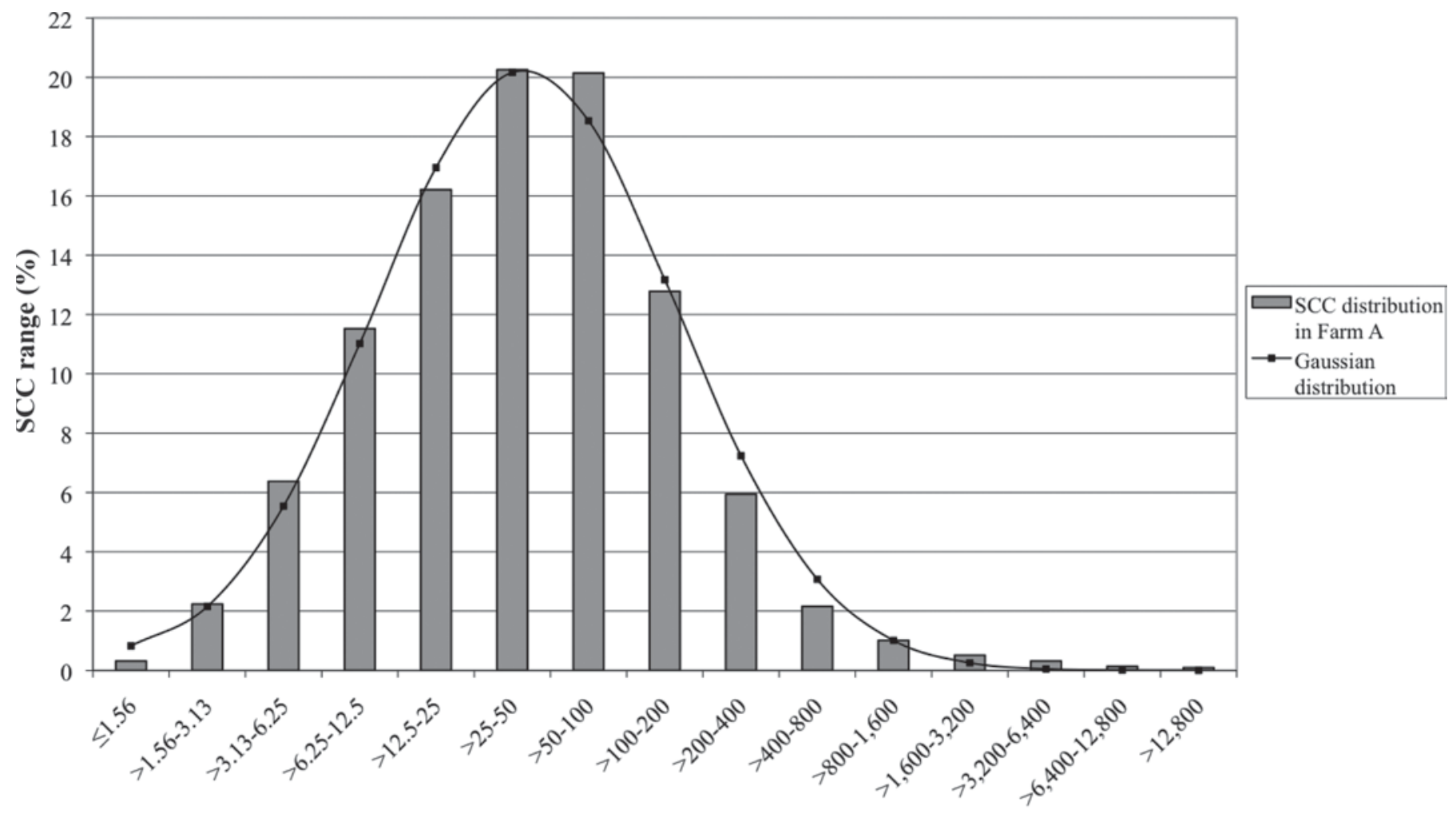

\section{SCC range $(\times 1,000$ cells $/ \mathrm{mL})$}

Figure 2. Statistical distribution of SCC of all quarter foremilk samples analyzed on farm A taken from 1995 to 2003 (n = 12,660) by classification into 15 SCC ranges using a logarithmic partition to the base 2 of the SCC scale according to the SCS standard. The bar charts show the distribution of SCC observed on farm A, and the line shows the distribution of SCC expected by the exact Gaussian distribution. 
Table 7. Prevalence and distribution of mastitis pathogens isolated from quarter foremilk samples taken on farm A between 1995 and $2003(\mathrm{n}=12,660)$

\begin{tabular}{lrcc}
\hline Item & $\mathrm{n}$ & $\begin{array}{c}\text { All quarters } \\
(\%)^{1}\end{array}$ & $\begin{array}{c}\text { Culture- } \\
\text { positive }(\%)^{2}\end{array}$ \\
\hline Quarters analyzed bacteriologically & 12,660 & & \\
Culture-negative quarters & 9,919 & 78.35 & \\
Culture-positive quarters & 2,741 & 21.65 & 5.29 \\
Staphylococcus aureus & 145 & 1.15 & 0 \\
Streptococcus agalactiae & 0 & 0 & 0.62 \\
Streptococcus dysgalactiae & 17 & 0.13 & 21.71 \\
Streptococcus uberis & 595 & 4.70 & 0.51 \\
Escherichia coli & 14 & 0.11 & 3.86 \\
Coliforms & 51 & 0.40 & 29.32 \\
CNS & 968 & 7.65 & 0.79 \\
Corynebacterium spp. & 820 & 6.48 & 3.98 \\
Other pathogens & 22 & 0.17 & \\
Contamination & 109 & 0.86 & \\
\hline
\end{tabular}

${ }^{1}$ Percentage of all quarters analyzed bacteriologically.

${ }^{2}$ Percentage of all culture-positive quarters.

${ }^{3}$ Coliforms $=$ Klebsiella spp., Serratia spp., Enterobacter spp., other Enterobacteriaceae.

${ }^{4}$ Other pathogens: Arcanobacterium pyogenes, Proteus, Prototheca zopfii, Pseudomonas spp., group G streptococci, yeasts, and fungi.

fraction has a substantial affect on SCC because milk secreted during the milking process has lower SCC than milk from pre- or postmilking (Olde Riekerink et al., 2007). However, the volume of foremilk varies from 5 to $60 \mathrm{~mL}$ (Fernando and Spahr, 1983; Vangroenweghe et al., 2002; Sarikaya and Bruckmaier, 2006). Sarikaya and Bruckmaier (2006) found a significant decrease of SCC comparing the first $10 \mathrm{~mL}$ of milk with the follow- ing $140 \mathrm{~mL}$ in udder quarters secreting $>100,000$ cells/ $\mathrm{mL}$, whereas this decrease was only moderate for udder quarters with a SCC $<100,000$ cells $/ \mathrm{mL}$. Comparing $\mathrm{SCC}$ in the first $5 \mathrm{~mL}$ of milk with the following $20 \mathrm{~mL}$ in infected and uninfected mammary glands, Fernando and Spahr (1983) reported slightly higher values for the first $5 \mathrm{~mL}$ of milk. In our study, foremilk was defined as the first $10 \mathrm{~mL}$ of milk collected from the teat after the

Table 8. Prevalence and distribution of mastitis pathogens (\%) isolated from quarter foremilk samples obtained in dairy farm A within the years 1995 to $2003(\mathrm{n}=12,660)$ in 15 different $\mathrm{SCC}$ ranges

\begin{tabular}{|c|c|c|c|c|c|c|c|c|c|c|c|c|}
\hline \multirow[b]{2}{*}{$\begin{array}{l}\text { Group/SCC range } \\
(\times 1,000 \text { cells } / \mathrm{mL})\end{array}$} & \multirow[b]{2}{*}{$\mathrm{n}$} & \multicolumn{6}{|c|}{ Major pathogens ${ }^{1}$} & \multicolumn{2}{|c|}{ Minor pathogens } & \multirow[b]{2}{*}{ Others $^{2}$} & \multirow[b]{2}{*}{$\begin{array}{c}\text { No } \\
\text { pathogens }\end{array}$} & \multirow[b]{2}{*}{ Contam. ${ }^{3}$} \\
\hline & & $\begin{array}{l}\text { Staph. } \\
\text { aureus }\end{array}$ & $\begin{array}{l}\text { Strep. } \\
\text { agalactiae }\end{array}$ & $\begin{array}{c}\text { Strep. } \\
\text { dysgalactiae }\end{array}$ & $\begin{array}{l}\text { Strep. } \\
\text { uberis }\end{array}$ & E. coli & Coliforms & CNS & $\begin{array}{l}\text { Coryne- } \\
\text { bacterium } \\
\text { spp. }\end{array}$ & & & \\
\hline \multicolumn{13}{|l|}{ Group I } \\
\hline$\leq 1.56$ & 40 & 0 & 0 & 0 & 0 & 0 & 0 & 2.50 & 0 & 0 & 97.50 & 0 \\
\hline$>1.56-3.13$ & 283 & 0 & 0 & 0 & 0 & 0 & 0 & 0.71 & 0.35 & 0 & 98.94 & 0 \\
\hline$>6.25-12.5$ & 1,459 & 1.24 & 0 & 0 & 0.14 & 0 & 0 & 0.34 & 0.14 & 0 & 98.14 & 0 \\
\hline$>12.5-25$ & 2,052 & 0.34 & 0 & 0 & 0.19 & 0 & 0 & 0.58 & 0.34 & 0 & 98.55 & 0 \\
\hline \multicolumn{13}{|l|}{ Group III } \\
\hline$>25-50$ & 2,564 & 0.55 & 0 & 0 & 0.08 & 0 & 0 & 0.74 & 0.31 & 0 & 98.32 & 0 \\
\hline$>50-100$ & 2,550 & 0.71 & 0 & 0 & 0.47 & 0 & 0.04 & 0.98 & 0.63 & 0.08 & 96.97 & 0.12 \\
\hline \multicolumn{13}{|l|}{ Group IV } \\
\hline$>100-200$ & 1,618 & 1.29 & 0 & 0.06 & 14.83 & 0.31 & 1.05 & 33.62 & 31.83 & 0.62 & 11.77 & 4.62 \\
\hline$>6,400-12,800$ & 17 & 0 & 0 & 5.88 & 35.29 & 0 & 0 & 17.64 & 11.76 & 11.76 & 17.67 & 0 \\
\hline$>12,800$ & 12 & 0 & 0 & 8.33 & 33.33 & 8.33 & 8.33 & 33.33 & 8.35 & 0 & 0 & 0 \\
\hline
\end{tabular}

${ }^{1}$ Major pathogens: Staphylococcus aureus; Streptococcus (Strep.) agalactiae; Strep. dysgalactiae; Strep. uberis; Escherichia coli; Coliforms = Klebsiella spp., Serratia spp., Enterobacter spp., other Enterobacteriaceae.

${ }^{2}$ Other pathogens: Arcanobacterium pyogenes, Proteus, Prototheca zopfii, Pseudomonas spp., group G streptococci, yeasts, and fungi.

${ }^{3}$ Contaminated samples. 
first 2 squirts were discarded. Therefore, we presume that our SCC values are representative for the analysis of the udder health status. Foremilk samples were taken from farms producing high quality milk, from conventional farms, and from farms with severe udder health problems. This random test of 615,187 quarter foremilk samples represented $12.5 \%$ of all Hessian cows. The large data set generated indicated that approximately two-thirds of all quarter foremilk samples lay in the physiological range of SCC $\leq 100,000$ cells $/ \mathrm{mL}$. This high frequency confirmed a proper level of udder health in the Hessian dairy cow population. The geometric mean of SCC in bulk milk samples in Hesse showed a value of 200,000 cells/mL in 2008 (HVL, 2009). Comparable data are available from the Netherlands, Belgium, and Finland. In the Netherlands, a geometric mean of SCC in bulk milk samples of 200,000 cells/mL was observed in 2002 (Sampimon et al., 2005). The geometric mean of SCC of bulk milk samples in Belgium was 221,000 cells/mL in 2006 (Piepers et al., 2007). In Finland, the geometric mean of bulk milk SCC was 132,000 cells/mL in 2002 (Pitkälä et al., 2004).

The statistical distribution of the logarithm of SCC of all quarter foremilk samples tested in the years 2000 to 2008 in Hesse did not exactly show a Gaussian distribution. The reasons for the deviation of the empirical distribution curve may be due to the very large sample size and the origin of the samples. The data were collected from dairy farms offering different levels of udder health. Using a logarithmic partition for the SCC scale, the empirical distribution of SCC was still skewed to the right. Fewer samples at the level of $\leq 3,130$ cells/ $\mathrm{mL}$ and a level of $>50,000$ to $1,600,000$ cells $/ \mathrm{mL}$ were observed than expected by exactly normally distributed values. In contrast, more samples lay in the range from $>3,130$ to 50,000 cells $/ \mathrm{mL}$ and at $\mathrm{SCC}>1,600,000$ cells $/ \mathrm{mL}$ than expected by normal distribution.

The distribution of SCC on dairy farm A showed $15 \%$ more samples in the SCC range $\leq 100,000$ cells/ $\mathrm{mL}$ than the Hessian average. This represented a very high standard of udder health in this high quality milkproducing farm and is due to exceptional hygiene management. The distribution of SCC on farm A differed from a Gaussian distribution for the same reasons as determined for the total Hessian random test, but the deviation was reduced.

The results of our study indicated that SCC in front quarters were significantly lower than in rear quarters, which is in agreement with the results of Schepers et al. (1997). Because high SCC is usually an indicator of an immune response to IMI with bacterial pathogens (Dohoo et al., 1984), a higher prevalence of pathogens should be expected in rear quarters. However, in our data set, the prevalence of bacteria differed between the individual quarters but these differences did not explain the higher SCC in rear quarters. Rear quarters might be more susceptible to infections than front quarters, as published previously (Pearson and Mackie, 1979), because of larger capacity and mass, greater vulnerability to direct trauma (e.g., horning), and greater exposure to environmental effects. In addition, teats of the rear quarters are frequently nearer the floor, especially in older cows, and would thus be contaminated or subjected to injury more readily.

In the Hessian survey in the period 2000 to 2003, SCC was used as a guideline for the selection of quarter foremilk samples for bacteriological analysis. The data showed $51.96 \%$ of samples to be culture-positive. Our results are comparable to those obtained from the Netherlands (Sampimon et al., 2009), Belgium (Piepers et al., 2007), and Finland (Pitkälä et al., 2004). Similar to results from Hesse (17.17\%), CNS were the most frequently isolated pathogens in the Netherlands, Belgium, and Finland (9.7 to $16.61 \%$ ). However, it is not clear whether IMI with CNS will always result in inflammation (Sampimon et al., 2009). High frequencies of isolation of Corynebacterium spp. have been noted in Hesse (13.56\%) and Finland (11.52\%), in contrast to the Netherlands and Belgium, where only 2.5 and $0.1 \%$ of the samples showed Corynebacterium spp., respectively. These differences were probably related to changes in herd management and bacteriological ecology in the herd environment (Pitkälä et al., 2004). The prevalence of Staph. aureus in the Netherlands, Belgium, and Finland (1.8 to 3.4\%) was lower than in Hesse (5.01\%). Implementation of standard mastitis prevention programs (Neave et al., 1969) led to a clear decrease of mastitis caused by Staph. aureus in many countries. In contrast to the low prevalence of Strep. uberis in the Netherlands and Finland (1.1 and 0.65\%, respectively), the prevalence of this species was higher in Belgium (2.7\%) and Hesse (8.7\%). These differences may originate from different hygiene and management systems in these countries, because Strep. uberis is an environmental pathogen. Streptococcus agalactiae showed a low prevalence in Hesse $(0.29 \%)$, Belgium $(0.1 \%)$, and Finland $(0.02 \%)$, but was not detected in any of the samples taken in the Netherlands in 2003. The implementation of mastitis prevention programs led to a clear reduction of the prevalence of Strep. agalactiae, too. The prevalence of Strep. dysgalactiae in Hesse $(0.83 \%)$ was similar to that in the Netherlands $(1.2 \%)$, but differed from that in Belgium $(0.4 \%)$ and Finland $(0.05 \%)$. The epidemiology of this pathogen is intermediate between contagious and environmental. When it is known which factors increase the incidence of IMI with these pathogens, the control program for Strep. dysgalactiae may need to be adjusted (Sampimon 
et al., 2009). The low prevalences of coliforms and $E$. coli observed in Hesse (1.15 and 0.61\%, respectively), Belgium ( $0.1 \%$ coliforms), and Finland ( $0.14 \%$ coliforms) were expected because these species are generally involved in acute clinical mastitis of short duration (Todhunter et al., 1991). In the Dutch study, E. coli was considered in the group of other bacteria because of only 2 isolations.

In our investigation, major pathogens (Staph. aureus, Strep. uberis) as well as minor pathogens (Corynebacterium spp., CNS) were detectable starting from an SCC level of 1,000 cells $/ \mathrm{mL}$. Similar data were found in a Dutch study (ten Napel et al., 2009). However, Staph. aureus is a natural species of mammalian skin and mucous epithelia (Sutra and Poutrel, 1994). Streptococcus uberis is considered an environmental pathogen (Radostits et al., 2007). Both major pathogens cause mastitis, which could take subclinical or clinical courses. Corynebacterium spp. readily colonize the teat canal of dairy cows (Brooks and Barnum, 1984). Coagulasenegative staphylococci are part of the normal teat skin flora and can colonize the teat canal (Devriese and De Keyser, 1980); some CNS species are detectable in the environment (White et al., 1989). In case of both minor pathogens, it is possible that they can contaminate the milk samples but not cause IMI (Linde et al., 1980). However, it is not clear whether the pathogens that we isolated from quarter foremilk samples with SCC values from 1,000 to 100,000 cells $/ \mathrm{mL}$ originated from contamination or whether they caused an IMI. In any case, no signs of an IMI were visible based on SCC. Further research is needed for a detailed evaluation of immunological processes in such udder quarters.

The results of the bacteriological examinations on farm A were similar to the Hessian survey, and the low prevalence of mastitis pathogens in the SCC range $\leq 100,000$ cells $/ \mathrm{mL}$ could be expected because of the exceptional level of hygiene management.

Somatic cell counts $>100,000$ cells $/ \mathrm{mL}$ are normally related to inflammatory processes inside the mammary gland. In the Hessian study, bacterial diagnosis was possible in approximately $83 \%$ of these cases. Negative bacteriological results in these cases could depend on spontaneous elimination of infection (Eberhart et al., 1979; Smith et al., 1985), intermittent shedding of the pathogens (Sears et al., 1990), or presence of antimicrobials or other inhibitors in milk (Reiter, 1978). At the time of examination, pathogens could also be ingested by phagocytes or survive intracellularly in the host (Newbould and Neave, 1965; Hill et al., 1978). Exudations of too-low masses of the pathogens or ceased growth of the pathogens are further reasons for negative results (Sears et al., 1990). Negative results following antibiotic therapies should be excluded in our study because of withdrawal period regulations.

An SCC range of $\leq 100,000$ cells $/ \mathrm{mL}$ is within the physiological range, but could be related to subclinical mastitis in the presence of pathogens. However, SCC values $\leq 100,000$ cells $/ \mathrm{mL}$ are normally not taken into account to evaluate inflammatory processes. Bacteria detected could also be derived from contamination of the skin, teat canal, or environment. We presume that not all of these bacteria contaminated the milk samples. Therefore, it is obvious that they originated from inside the mammary gland and might cause an IMI even in the SCC range $<100,000$ cells $/ \mathrm{mL}$.

Our data showed that in $62 \%$ of all udder quarters SCC $\leq 100,000$ cells/mL were detected, suggesting a high standard of udder health in the Hessian dairy cow population analyzed. In view of the mastitis pathogens, prevalences were clearly lower in samples with $\leq 100,000$ cells/mL than in samples with $>100,000$ cells $/ \mathrm{mL}$. This finding confirmed the 100,000 cells/mL threshold differentiating infected from noninfected mammary glands. However, our data also indicated that minor and major pathogens were detected even at a minimum of 1,000 cells $/ \mathrm{mL}$. This result led us to suspect inflammatory processes in the SCC range $\leq 100,000$ cells $/ \mathrm{mL}$. We assert that these inflammatory processes could be elucidated by examination of the relationship of immune cells in milk. Differential cell counts might be a better indicator than SCC for a profound evaluation of inflammation, especially at SCC levels $\leq 100,000$ cells/ $\mathrm{mL}$.

\section{ACKNOWLEDGMENTS}

The authors are grateful to U. Eskens, U. Kaiser, and K. Risse (Landesbetrieb Hessisches Landeslabor, Giessen, Germany) for their excellent technical assistance. We thank all dairy farms for their excellent cooperation. Furthermore, we thank Renata Piccinini (Department of Animal Pathology, Hygiene and Public Health, Università degli Studi di Milano, Milan, Italy) and Gabriel Leitner (National Mastitis Reference Center, Kimron Veterinary Institute, Bet Dagan, Israel) for critical reading of the manuscript.

\section{REFERENCES}

Ali, A. K. A., and G. E. Shook. 1980. An optimum transformation for somatic cell concentration in milk. J. Dairy Sci. 63:487-490.

Brooks, B. W., and D. A. Barnum. 1984. Experimental colonization of the bovine teat duct with Corynebacterium bovis and the effect on milk somatic cell counts. Can. J. Comp. Med. 48:141-145.

Devriese, L. A., and H. De Keyser. 1980. Prevalence of different species of coagulase-negative staphylococci on teats and in milk samples from dairy cows. J. Dairy Res. 47:155-158. 
Dohoo, I. R., and A. H. Meek. 1982. Somatic cell counts in bovine milk. Can. Vet. J. 23:119-125.

Dohoo, I. R., A. H. Meek, and S. W. Martin. 1984. Somatic cell counts in bovine milk: relationships to production and clinical episodes of mastitis. Can. J. Comp. Med. 48:130-135.

DVG (German Veterinary Society). 2000. Entnahme von Milchproben unter aseptischen Bedingungen. Sachverständigenausschuss "Subklinische Mastitis." DVG, Giessen, Germany.

DVG (German Veterinary Society). 2002. Leitlinien zur Bekämpfung der Mastitis als Bestandsproblem. Sachverständigenausschuss "Subklinische Mastitis." DVG, Giessen, Germany.

Eberhart, R. J., R. P. Natzke, F. H. S. Newbould, B. Nonnecke, and P. Thompson. 1979. Coliform mastitis-A review. J. Dairy Sci. 62:1-22.

Fernando, R. S., and S. L. Spahr. 1983. Effects of milking interval on selected milk constituents from normal and infected quarters. J. Dairy Sci. 66:1155-1161.

Harmon, R. J. 1994. Physiology of mastitis and factors affecting somatic cell counts. J. Dairy Sci. 77:2103-2112.

Hill, A. W. A. L. Shears, and K. G. Hibbitt. 1978. The elimination of serum-resistant Escherichia coli from experimentally infected single mammary glands of healthy cows. Res. Vet. Sci. 25:89-93.

HVL (Hessischer Verband für Leistungs- und Qualitätsprüfungen in der Tierzucht). 1994. Annual Report 1993. HVL, Alsfeld, Germany.

HVL (Hessischer Verband für Leistungs- und Qualitätsprüfungen in der Tierzucht) 2009. Annual Report 2008. HVL, Alsfeld, Germany.

IDF. 1981. Laboratory Methods for Use in Mastitis Work. Document 132. International Dairy Federation, Brussels, Belgium.

König, S., R. Sharifi, H. Wentrot, D. Landmann, M. Eise, and H Simianer. 2005. Genetic parameters of claw and foot disorders estimated with logistic models. J. Dairy Sci. 88:3316-3325.

LHL (Landesbetrieb Hessisches Landeslabor). 2009. Annual Report 2008. LHL, Giessen, Germany.

Linde, C., O. Holmberg, and G. Aström. 1980. The interference between coagulase negative staphylococci and Corynebacterium bovis and the common udder pathogens in the lactating cows. Nor. Vet. Med. 32:552-558

Littell, R., G. Milliken, W. Stroup, and R. Wolfinger. 1999. SAS system for mixed models. SAS Institute Inc., Cary, NC.

Makovec, J. A., and P. L. Ruegg. 2003. Results of milk samples submitted for microbiological examination in Wisconsin from 1994 to 2001. J. Dairy Sci. 86:3466-3472.

Myllys, V., K. Asplund, E. Brofeldt, V. Hirvelä-Koski, T. HonkanenBuzalski, J. Junttila, L. Kulkas, O. Myllykangas, M. Niskanen, H. Saloniemi, M. Sandholm, and T. Saranpää. 1998. Bovine mastitis in Finland in 1988 and 1995 - Changes in prevalence and antimicrobial resistance. Acta Vet. Scand. 39:119-126.

Neave, F. K., F. H. Dodd, R. G. Kingwill, and D. R. Westgarth. 1969. Control of mastitis in the dairy herd by hygiene and management. J. Dairy Sci. 52:696-707.

Newbould, F. H. S., and F. K. Neave. 1965. The recovery of small numbers of Staphylococcus aureus infused into the bovine teat cistern. J. Dairy Res. 32:157-162.

Nightingale, C., K. Dhuyvetter, R. Mitchell, and Y. Schukken. 2008. Influence of variable milk quality premiums on observed milk quality. J. Dairy Sci. 91:1236-1244.

Olde Riekerink, R. G. M., H. W. Barkema, W. Veenstra, F. E. Berg, H. Stryhn, and R. N. Zadoks. 2007. Somatic cell counts during and between milkings. J. Dairy Sci. 90:3733-3741.

Pearson, J. K. L., and D. P. Mackie. 1979. Factors associated with the occurrence, cause and outcome of clinical mastitis in dairy cattle. Vet. Rec. 105:456-463.

Piepers, S., L. De Meulemeester, A. de Kruif, G. Opsomer, H. W. Barkema, and S. De Vliegher. 2007. Prevalence and distribution of mastitis pathogens in subclinically infected dairy cows in Flanders, Belgium. J. Dairy Res. 74:478-483.

Pitkälä, A., M. Haveri, S. Pyörälä, V. Myllys, and T. Honkanen-Buzalski. 2004. Bovine mastitis in Finland 2001—Prevalence, dis- tribution of bacteria, and antimicrobial resistance. J. Dairy Sci $87: 2433-2441$.

Radostits, O. M., C. C. Gay, K. W. Hinchcliff, and P. D. Constable 2007. Veterinary Medicine: A textbook of the diseases of cattle, horses, sheep, pigs, and goats. 10th ed. W. B. Saunders Company, Philadelphia, PA.

Reiter, B. 1978. Review of progress of dairy science-Anti-microbial systems in milk. J. Dairy Res. 45:131-147.

Reneau, J. K. 1986. Use of dairy herd improvement somatic cell counts in mastitis control. J. Dairy Sci. 69:1708-1720.

Reneau, J. K., and V. L. Packard. 1991. Monitoring mastitis, milk quality and economic losses in dairy fields. Dairy Foods Environ. Sanit. 11:4-11.

Sampimon, O., H. W. Barkema, I. Berends, J. Sol, and T. Lam. 2009. Prevalence of intramammary infection in Dutch dairy herds. J. Dairy Res. 76:129-136.

Sampimon, O., J. Sol, and P. Kock. 2005. Changes in bulk milk somatic cell count and distribution of mastitis pathogens over the past 50 years in the Netherlands. Pages 963-968 in Proceedings of the 4th IDF International Mastitis Conference, Maastricht, the Netherlands. Wageningen Academic Publishers, Wageningen, the Netherlands.

Sarikaya, H., and R. M. Bruckmaier. 2006. Importance of the sampled milk fraction for the prediction of total quarter somatic cell count. J. Dairy Sci. 89:4246-4250.

Schepers, A. J., T. J. G. M. Lam, Y. H. Schukken, J. B. M. Wilmink, and W. J. A. Hanekamp. 1997. Estimation of variance component for somatic cell counts to determine thresholds for uninfected quarters. J. Dairy Sci. 80:1833-1840.

Schukken, Y. H., D. J. Wilson, F. Welcome, L. Garrison-Tikofsky, and R. N. Gonzalez. 2003. Monitoring udder health and milk quality using somatic cell counts. Vet. Res. 34:579-596.

Sears, P. M., B. S. Smith, P. B. English, P. S. Herer, and R. N. Gonzalez. 1990. Shedding pattern of Staphylococcus aureus from bovine intramammary infections. J. Dairy Sci. 73:2785-2789.

Seegers, H., C. Fourichon, and F. Beaudeau. 2003. Production effects related to mastitis and mastitis economics in dairy cattle herds. Vet. Res. 34:475-491.

Smith, K. L., D. A. Todhunter, and P. S. Shoenberger. 1985. Environmental mastitis: Cause, prevalence, prevention. J. Dairy Sci 68:1531-1553.

Stockler, R. M., D. E. Morin, R. K. Lantz, W. L. Hurley, and P. D. Constable. 2009. Effect of milk fraction on concentrations of cephapirin and desacetylcephapirin in bovine milk after intrammamary infusion of cephapirin sodium. J. Vet. Pharmacol. Ther. $32: 345-352$.

Sutra, L., and B. Poutrel. 1994. Virulence factors involved in the pathogenesis of bovine intramammary infections due to Staphylococcus aureus. J. Med. Microbiol. 40:79-89.

ten Napel, J., Y. de Haas, G. de Jong, T. J. G. M. Lam, W. Ouweltjes, and J. J. Winding. 2009. Characterization of distributions of somatic cell counts. J. Dairy Sci. 92:1253-1264.

Todhunter, D. A., K. L. Smith, J. S. Hogan, and P. S. Schoenberger. 1991. Gram-negative bacterial infections of the mammary gland in cows. Am. J. Vet. Res. 52:184-188.

Vangroenweghe, F., H. Dosogne, and C. Burvenich. 2002. Composition and milk cell characteristics in quarter milk fractions of dairy cows with low cell count. Vet. J. 164:254-260.

Viguier, C., S. Arora, N. Gilmartin, K. Welbeck, and R. O'Kennedy. 2009. Mastitis detection: current trends and future perspectives. Trends Biotechnol. 27:486-493.

White, D. G., R. J. Harmon, J. E. Matos, and B. E. Langlois. 1989. Isolation and identification of coagulase-negative Staphylococcus species from bovine body sites and streak canals of nulliparous heifers. J. Dairy Sci. 72:1886-1892.

Wolfinger, R., and M. O'Connell. 1993. Generalized linear mixed models: A pseudo-likelihood approach. J. Statist. Comput. Simulation 48:233-243. 